\title{
JOURNAL.RU
}

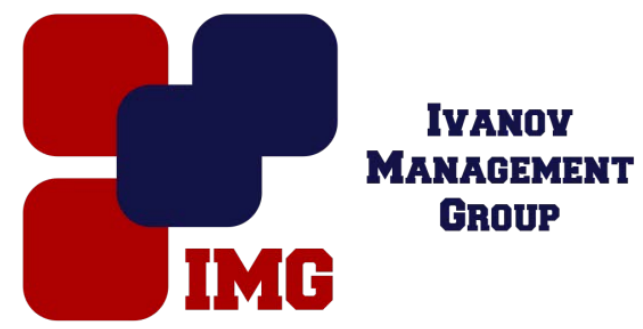

Костыкова М.Ю.

Воронежский институт ГПС МЧС

Воронеж, Россия

doi: 10.18411/lj-25-12-2016-3-12

idsp 000001:lj-25-12-2016-3-12

\section{Перспективы краудфандинга как инструмента венчурного финансирования малого бизнеса в РФ}

\section{Аннотация}

Раскрывается суть краудфандинга как одного из способов венчурного финансирования. Проведен обзор существующих препятствий роста спроса на краудфундинг. Выявлены основные пути развития краудфандинга для субъектов малого бизнеса в РФ.

Ключевые слова: краудфандинг, венчурное финансирование, малый бизнес, предпринимательство, риск.

За последние 10-15 лет экономика России претерпела значительные структурные изменения, большая часть которых коснулась вопросов положения малого бизнеса в стране и его вклада в валовой внутренний продукт страны.

В связи с сокращением количества предприятий с государственным участием в РФ постепенно развивается тенденция к самозанятости населения, а, следовательно, и растет малый бизнес.

Однако остается ключевая проблема финансирования малых организаций поиск доступных источников привлеченных средств. В условиях ограниченности предложений для малого бизнеса со стороны банковских и других кредитных организаций, субъекты предпринимательства пытаются найти альтернативные источники кредитных ресурсов, среди которых фигурируют разнообразные кооперативные инвестиционные сообщества, получившие импульс к развитию в последние несколько лет благодаря расширению сети Интернет. Среди них особенно ярко выглядят проекты, предлагающие Р2Р-финансирование и краудфандинг. Он, как правило, предполагает возвратность инвестиций (полную или частичную), а также прибыльность вложений. В качестве компенсации вложенных средств инвестор может получить бонус, например, образец продукции, выпускаемой новым предприятием, долговые обязательства стартапа или его акции.

Помимо использования Интернета, у краудфандинга есть ряд преимуществ - об этом свидетельствует исследование Департамента социологии Финансового университета, проведенное в декабре 2014 года [1]. 
Среди преимуществ и перспектив развития краудфандинга в РФ выделим несколько положений:

- четкая целевая направленность инвестиций: участники знают, на какой проект и цель будут направлены средства (в отличие от вкладчиков в банках), что повышает прозрачность и привлекательность процесса краудфандинга;

- благодаря знакомству инвестора и организатора проекта возникает эмоциональная реакция и чувство сопричастности инвестора к проекту, который кажется значимым, интересным и социально важным;

- привлекательность краудфандинга за счет отсутствия посредников позволяет получить более высокую рентабельность вложений. Заемщик, со своей стороны, по той же причине рассчитывает на снижение стоимости привлекаемых средств;

- поддерживаемая и поощряемая обществом форма финансирования инвестора, мотивация к участию состоит в желании помочь людям;

- краудфандинг выступает как социальная сеть, новый способ приобрести новых друзей, как своего рода ролевая игра, «окно» для участие в активной социальной жизни;

- к краудфандингу в первую очередь готовы обратиться предприниматели, испытывающие затруднения с получением банковского кредита, так как инвестиции через интернет-площадки оказываются более доступными малому бизнесу, не имеют жестких требований к заемщикам;

- краудфандинговый проект может рассматриваться как реклама нового проекта или маркетинговое исследование, нацеленное на оценку спроса на продукт, которое гораздо дешевле обычной рекламы;

- облегчение процесса поддержки искусства и культуры, генерирование дополнительного дохода для индустрии развлечений [3];

- поддержка инновационных решений и стартапов, что позволит традиционным посредникам находить новые таланты.

Однако на современном этапе становления краудфандинга есть масса барьеров развития. В первую очередь, это сложность привлечения финансирования, так как источником средств служат взносы участников, размер которых, не велик. Кроме того, незначительная прибыль проектов не предоставляет стимула для развития краудфандинга. Недостаточная нормативная база инвестирования в РФ, отсутствие методик оценки финансового состояния заемщиков осложняют процесс инвестирования. Основой его служат расчеты самого предпринимателя, мнение инвесторов. Необходимо внедрение рейтингов заемщиков (как в Р2Р-финансировании).

Отметим, что, несмотря на планы краудфандинговых площадок занять 5\% всего рынка финансов в РФ в среднесрочной перспективе, слабая информационная поддержка венчурной индустрии [2], низкий уровень инвестиционной культуры, а также отсутствие экономических стимулов и гибкой системы налогообложения для привлечения финансов в венчурные проекты могут повлиять на развитие сегмента отечественного краудфандинга. 


\section{Литература}

1. Зубец А.В. Социальная привлекательность альтернативных источников инвестиций в современной России (по материалам социологического исследования) // Вестник Финансового университета.-2015.- №3, С. 51-56.

2. Ларионов Н.А. Развитие новых моделей венчурного финансирования // Вестник Саратовского государственного социально-экономического университета. - 2013.-№3, С. 129-132.

3. Юрченко А.А., Кузнецова В.А. Краудфандинг - новый способ финансирования // Актуальные проблемы авиации и космонавтики. Том 2. - 2015.- №11, C.830-832. 